\title{
EDIBLE INSECTS VALUE CHAIN IN CROSS RIVER STATE, NIGERIA".
}

\section{SIMON IDOKO OKWECHE AND VICTOR ABANYAM ATAH}

(Received 4 December 2018; Revision Accepted 8 February 2019)

\begin{abstract}
A survey work on the benefits of entomophagous insects was carried out in four Local Government Areas of Central Zone of Cross River State, Nigeria to assess the most preferred and most consumed edible insect species. Three communities were selected from each Local Government Area. Three hundred and twenty (320) structured questionnaires were administered to the selected sampling population. The data were processed and subjected to statistical analysis such as descriptive and percentages as well analysis of variance. The result showed that insects consumed (bug, beetle, termite, bee, caterpillar, grasshopper and cricket) cut across the following Orders: Coleoptera, Orthoptera, Isoptera, Lepidotera, Hemiptera and Diptera. The Order Coleoptera had the highest number of species followed closely by the Orders Isoptera and Orthoptera. The insects were harvested/collected by the consumers from the wild at different periods of the year and prepared for consumption either by boiling, frying, roasting or sun drying while some were consumed raw. Rural dwellers majorly children are the major consumers of edible insects. These insects form an integral part of the diet of the people of the Central Part of the State.
\end{abstract}

KEYWORDS: Entomophagy, rural dwellers, Cross River, Local Government Area

\section{INTRODUCTION}

The increase in human population in the world today and the projected population growth of over 9.7 billion by the year 2050 has created high interest in food security. According to Affairs' World Population Prospects of 2015 , of the 2.4 billion additional growths in human population, from 2015 to 2050 , Africa will have a share of 1.3 billion, Asia 0.9 billion and the other 0.2 billion from the rest of the world. It was estimated that nearly 842 million people (12\% of the global population) were unable to meet their dietary energy requirements in 2010 to 2015 (Van Huis et al., 2015). The vast majority of the hungry people (827 million) live in developing regions, where the prevalence of undernourishment was at $15 \%$ in 2011 to 2013 . Lack of animal protein in human diets is quite alarming in Africa and other developing nations of the world which may be linked with high rate of infant and maternal mortality (UNICEF, 2015). Insect consumption has been known to be part of human diets for centuries and this has been a common culture in many parts of the world including Africa and Asia. It is however a taboo in some societies (Gordon, 1998; Okore et al., 2014; Ebenebe et al., 2017). Farming insects for human and animal consumption has not been given attention in most African countries, including Nigeria with a few exceptions such as bees and silkworm (Van Leneren, 2006). Knowledge of edible insects rearing is still lacking and may have contributed to the lack of widespread knowledge on its use (Van Huis 2013; Van Huis et al., 2015). Insects consumption is affected by cultural and religious practices while insects are commonly consumed as a food source in many parts of Nigeria, some people dislike the consumption of insects and associate it with primitive behaviour. Insects as a source of food and feed security are relevant in the $21^{\text {st }}$ century due to the increasing demand among the middle classes and the rising cost of animal protein, population growth and environmental pressures (Adeoye et al., 2014). In Nigeria, the most commonly consumed insects are larvae and adults of beetles (Coleoptera), larvae of the Saturnid Caterpillar (Cirinaforda) and Bunaea alcinoe (Lepidoptera) (Adegbola, 2013), winged termites Macrotermes bellicosus) (Isoptera), grasshoppers (Zonocerus variegatus), locusts (Locusta migratoria migratoroides (R. and F.) and crickets (Brachytrupes membranaceus (Drury), Gryllus bimaculatus (De Geer) (Orthoptera), cicadas (Magicicada spp.), leafhoppers and planthoppers, scale insects and true bugs (Hemiptera) katydids and dragon nymphs (Srivastava et al., 2009; Banjo et al., 2006). These insects are consumed either in one or more of the stages of

Simon Idoko Okweche, Department of Forestry and Wildlife Resources Management, University of Calabar, Calabar, Cross River State, Nigeria.

Victor Abanyam Atah, Department of Vocational Education, University of Calabar, Calabar, Cross River State, Nigeria. 
development in the life history of an insect (egg, larva, pupa and adult). The edible insect resource is primarily a category of Non-Timber Forest Products (NTFPs) collected from natural resources (Boulidam, 2010; Muafor, et al., 2012). The sustainable utilization of these edible insects will compensate and improve protein intake in rural areas. The main objective of this study was to identify edible insects in Cross River State, Nigeria and assess their socio-economic benefits to the rural communities.

\section{Materials and Methods}

\subsection{Study area}

This research was carried out in four Local Government Areas (LGA) of Cross River State comprising of Boki, Etung, Ikom and Yakurr respectively (see Figure 1). The local government areas were selected using purposive sampling method based on the fact that the people in the study areas are known for the consumption of insects due to the habitat which harbours the insects and they have the largest forest covers in the state (Akpabio et al., 2006). The study area is located in the rainforest zone and is sandwiched between longitude $5.51^{\circ}$ and $6.40^{\circ} \mathrm{N}$ and latitude $8.10^{\circ}$ and $8.5^{\circ} \mathrm{E}$ of the equator (Bulktrade, 1989). The area is predominantly forest region with clearly identified farm levels of which $50 \%$ is cropped and the other $50 \%$ occupied by forest (Akpan-Idiok. 2010). The LGAs are bounded by Obanliku, Obudu, and Ogoja LGA in the North, Republic of Cameroon in the East, Ebonyi State in the West, and Obubra Local Government in the South. The people of the study area are mainly farmers and the area is well suited for the production of permanent crops (like cocoa, oil palm, plantain, banana and cocoa) and arable crops such as yam, cassava, groundnut, maize, melon. The topography of Boki LGA is characterized by undulating relief, forested ridges with steep valleys while that of Etung, Ikom and Yakurr is on the level plain surface which gives the soil its characteristic red, to dark clay loam with patches of basaltic soil in some areas. The average temperature during the wet season is within the range of $27^{\circ} \mathrm{C}$ and increases to nearly $40^{\circ} \mathrm{C}$ in the dry season with relative humidity of $70-80 \%$ (Akpabio et al., 2006). The area is characterized by high rainfall with an average of $3,000 \mathrm{~mm}$ per annum being recorded, while the dry season lasts for up to four (4) months (December to March).

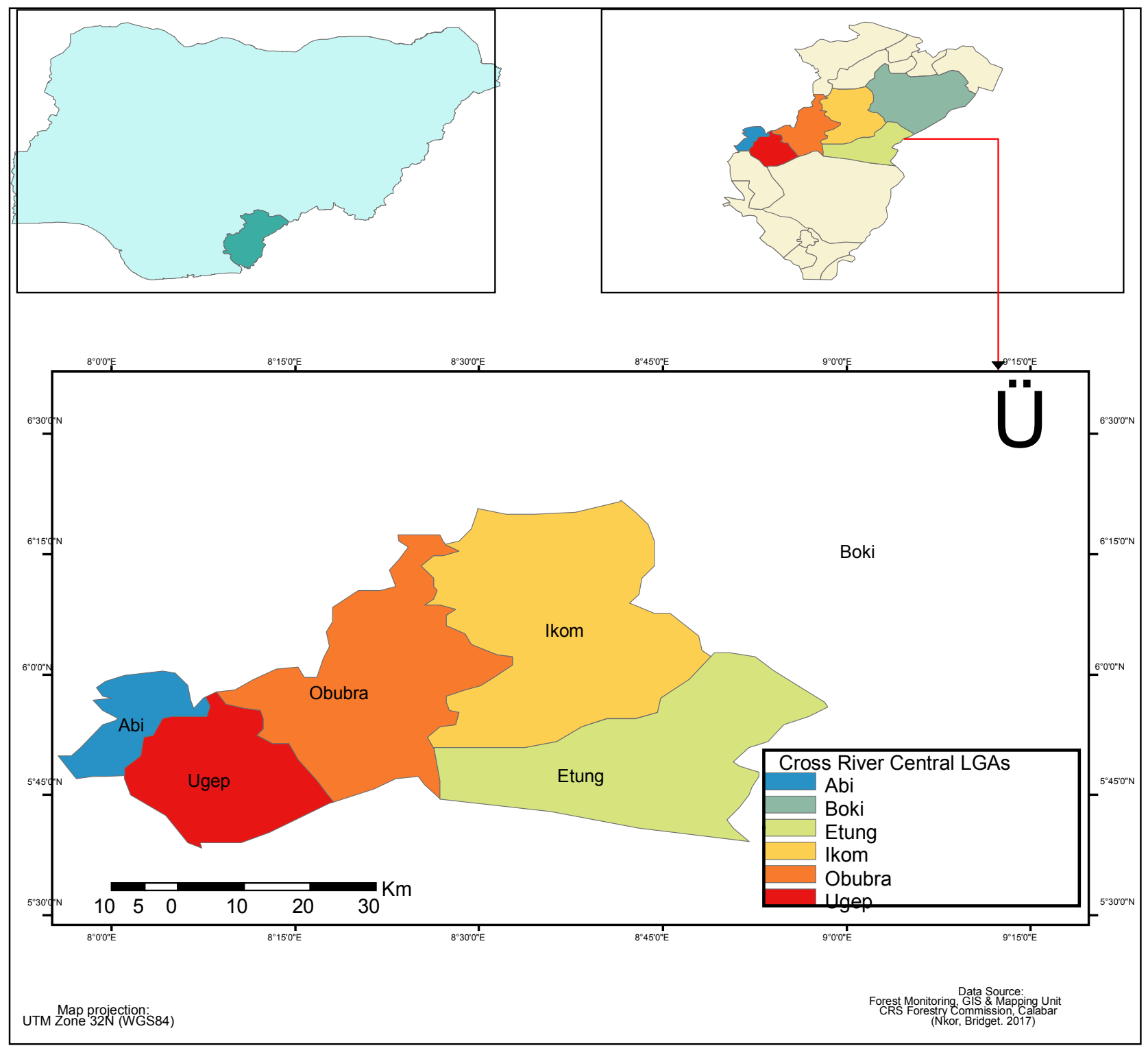

Figure 1: Map showing the location of Cross River Central 


\subsection{Population of the study}

The study area which is located in Cross River Central (CRC) has a projected population of eight hundred and thirty eight thousand $(838,000)$ (National Population Commission, 2006). Three communities from each LGA were selected using purposive sampling based on the availability of the edible insects as a result of forest cover. Eighty (80) respondents were chosen from each local government area and a total of 320 respondents were purposively selected for the entire study area (Table 1). The 320 subset sample included farmers, students, civil servants and traders.

Table 1: Population of the sampled LGAs

\begin{tabular}{lllll}
\hline LGAs & $\begin{array}{l}\text { Actual } \\
(2006)\end{array}$ & $\begin{array}{l}\text { Projection } \\
(2017)\end{array}$ & $\begin{array}{l}\text { Population } \\
\text { sampled }\end{array}$ & $\begin{array}{l}\text { Population } \\
\text { community }\end{array}$ \\
\hline Boki & 186,611 & 249,400 & 238 & 95 \\
Etung & 80,036 & 107,000 & 102 & 41 \\
lkom & 163,691 & 218,800 & 209 & 84 \\
Yakurr & 196,271 & 262,800 & 251 & 100 \\
& & & 800 & 320 \\
\hline
\end{tabular}

Table 2: Age distribution and marital status of the respondents

\begin{tabular}{lcccc}
\hline Age group & Boki & Ikom & Etung & Yakurr \\
\hline & & & & \\
$0-18$ & 16 & 14 & 15 & 24 \\
$19-36$ & 27 & 25 & 28 & 19 \\
$37-54$ & 27 & 30 & 13 & 19 \\
$55-72$ & 14 & 15 & 26 & 20 \\
73 and above & 16 & 16 & 18 & 18 \\
& & & & \\
Single & 40 & Marital Status & 32 & 40 \\
Married & 50 & 42 & 56 & 45 \\
Divorce & 10 & 09 & 12 & 15 \\
\hline
\end{tabular}

\subsection{Sampling techniques}

Purposive sampling technique was used (i.e. the sampling technique in which researcher relies on his or her own discretion in the choice of members of population to participate in the study) to collect data for this study. The CRC consists of 6 LGAs based on political and ethnic groups in the state. Information was collected using well- structured questionnaire/ oral interviews. In situations where the respondent was not literate, structured oral interview was used with the questions asked exactly as appeared in the questionnaire and responses recorded by the interviewer.

\subsection{Data collection instrument}

The questionnaires consisted of a list of questions that were administered to the respondents to obtain information on edible insects in the four (4) LGAs of CRC which consist of Boki, Etung, Ikom and Yakurr respectively. They were interviewed with an open ended question that required them to list potential households where insect collection and trade was practiced. The structured questionnaires containing 20 questions allowed respondents to make personal decisions based on individual degree of rating contained in the questions yes or no. Different ages were accessed to ascertain how entomophagy as a practice spreads across the population. The respondents' ages were determined using a range of $0-18,19-36,37-54,55-72$, and 73 above.

Based on the responses from the collected data, a detailed list of the insect species consumed as food in the study area was documented. Percentages were calculated to show the differences in preference for the various species listed and how the practice spreads among the ages accessed while a bar chart was used to represent how the various insects are consumed across the LGAs.

Questions like what species of insects are harvested for trade, where are the beetles harvested, who harvests the beetles, how are harvested beetles preserved, where are the beetles sold, how much are the beetles sold and how much does the insect trade contribute to households income were asked to obtain socioeconomic information on the insects. Information obtained from the respondents were coded. For each question, separate list of codes were kept and new codes were created as new themes emerged. This coding process allowed the answers given in narrative form to be listed in the form of figure for better analysis. 
2.6 Data analysis techniques

The data collected for this study were subjected to descriptive and inferential statistical analysis. Some data were analyzed using tables and percentage; while some were subjected to analyses of variance (ANOVA) using StatView statistical software for windows. The significance level was set to $p \leq 0.05$.

\section{RESULTS}

\subsection{Socio-demographic characteristics of the respondents}

Results from this study revealed that Cross Riverians consumed a variety of insects and they attached great values to it. The ages of most of the respondents ranged between 0 to 18 and 70 years and above in all the communities sampled (Table 2) with $50 \%$ married, $40 \%$ singles and $10 \%$ of the respondents in the category of divorcee (Table 2). In the sampled areas (Boki, Ikom, Etung, and Yakurr), respondents included students, teachers, traders and civil servants.

\subsection{The insects consumed in the various LGAs}

The result revealed that about 7 different insects are consumed by the people of CRC which included water bug (Lethocerus sp), Palm beetles (Oryctes rhinoceros $\mathrm{L}$ ), termite (Macrotermes bellicosus), crickets (Brachytrupes membranaceus (Drury), caterpillars (Bunaea alcinoe), bees (Apis mellifera), grasshoppers (Zonocerus variegates (Linn) and others which constituted the unidentified. The results showed that in Boki LGA, $3 \%$ of the respondents consume bees, $26 \%$ beetle, $1 \%$ bug, $13 \%$ caterpillar, $22 \%$ cricket, $6 \%$ grasshopper, $26 \%$ termite and $3 \%$ unidentified insects. Similar trends were observed in other LGAs (Table 3)

Table 3: Insect species consumed in Cross River Central

\begin{tabular}{lcccc}
\hline \multicolumn{5}{c}{ LGAs } \\
\hline Edible insects & Boki & Etung & Ikom & Yakurr \\
\hline Bees & $12.67^{\mathrm{d}} \pm 2.52$ & $13.00^{\mathrm{d}} \pm 2.00$ & $14.00^{\mathrm{a}} \pm 2.00$ & $11.33^{\mathrm{d}} \pm 3.79$ \\
Beetles & $99.87^{\mathrm{a}} \pm 0.58$ & $94.00^{\mathrm{a}} \pm 4.00$ & $99.67^{\mathrm{a}} \pm 0.58$ & $99.67^{\mathrm{a}} \pm 0.58$ \\
Bugs & $3.00^{\mathrm{c}} \pm 1.00$ & $3.00^{\mathrm{e}} \pm 1.00$ & $1.33^{\mathrm{e}} \pm 0.58$ & $8.00^{\mathrm{d}} \pm 2.00$ \\
Caterpillars & $55.67^{\mathrm{b}} \pm 1.53$ & $62.67^{\mathrm{b}} \pm 2.52$ & $63.67^{\mathrm{b}} \pm 4.04$ & $75.00^{\mathrm{b}} \pm 5.00$ \\
Cricket $\mathrm{s}$ & $80.67^{\mathrm{a}} \pm 8.45$ & $94.67^{\mathrm{a}} \pm 7.57$ & $98.00^{\mathrm{a}} \pm 2.00$ & $93.67^{\mathrm{a}} \pm 3.51$ \\
Grasshoppers & $25.00^{\mathrm{c}} \pm 5.00$ & $35.00^{\mathrm{c}} \pm 5.00$ & $38.67^{\mathrm{c}} \pm 7.02$ & $45.33^{\mathrm{c}} \pm 4.16$ \\
Termites & $98.00^{\mathrm{a}} \pm 2.00$ & $99.67 \mathrm{a} \pm 0.58$ & $99.33^{\mathrm{a}} \pm 0.58$ & $99.67^{ \pm} \pm 0.58$ \\
Others & $12.67^{\mathrm{d}} \pm 1.53$ & $32.33^{\mathrm{c}} \pm 2.52$ & $11.00^{\mathrm{d}} \pm 2.00$ & $38.00^{\mathrm{c}} \pm 2.00$ \\
\hline
\end{tabular}

Means within a column followed by the same letter do not differ significantly by Least Significant Difference Test (LSD) at $5 \%$ of probability

\subsection{Abundance of the edible insects}

Amongst the insects consumed, beetles, termites and crickets constituted the highest percentage followed by caterpillars while bees and bugs constituted the least of all the consumed insect species. The result showed a significant difference in the species of edible insects consumed in the sampled local government areas (Table 3). Higher percentage (over70 \%) of the insects are consumed in the rural areas while less than $30 \%$ of it taken to the urban with the exceptions of bees where $50 \%$ of the products are consumed both in the urban and rural areas (Figure 2). In the rural areas, $75 \%$ bug (Lethocerus sp), $80 \%$ beetles (O. rhinoceros), $78 \%$ termites (M. bellicosus), $80 \%$ caterpillar (B. alcinoe), 85 $\%$ grasshoppers (Z. variegatus), and $95 \%$ crickets (B. membranaceus) are consumed compared with urban (Table 3).

\subsection{Harvesting period of edible insects}

Significant difference was found on the time of harvesting with termites and cricket the two edible insects that are harvested during the rainy season (from April to September). Bugs (Lethocerus $\mathrm{sp}$ ), beetles ( $O$. rhinoceros), bees ( $A$. mellifera), grasshoppers ( $Z$. variegatus) and caterpillars (B. alcinoe) are however harvested both in dry and rainy seasons and peak is between March and April. However, they are found all year round in all the communities. A greater proportion of bees, beetles (O. rhinoceros) and caterpillars $(B$. alcinoe) are harvested during the dry season (November to March) of the year (Figure 3). 


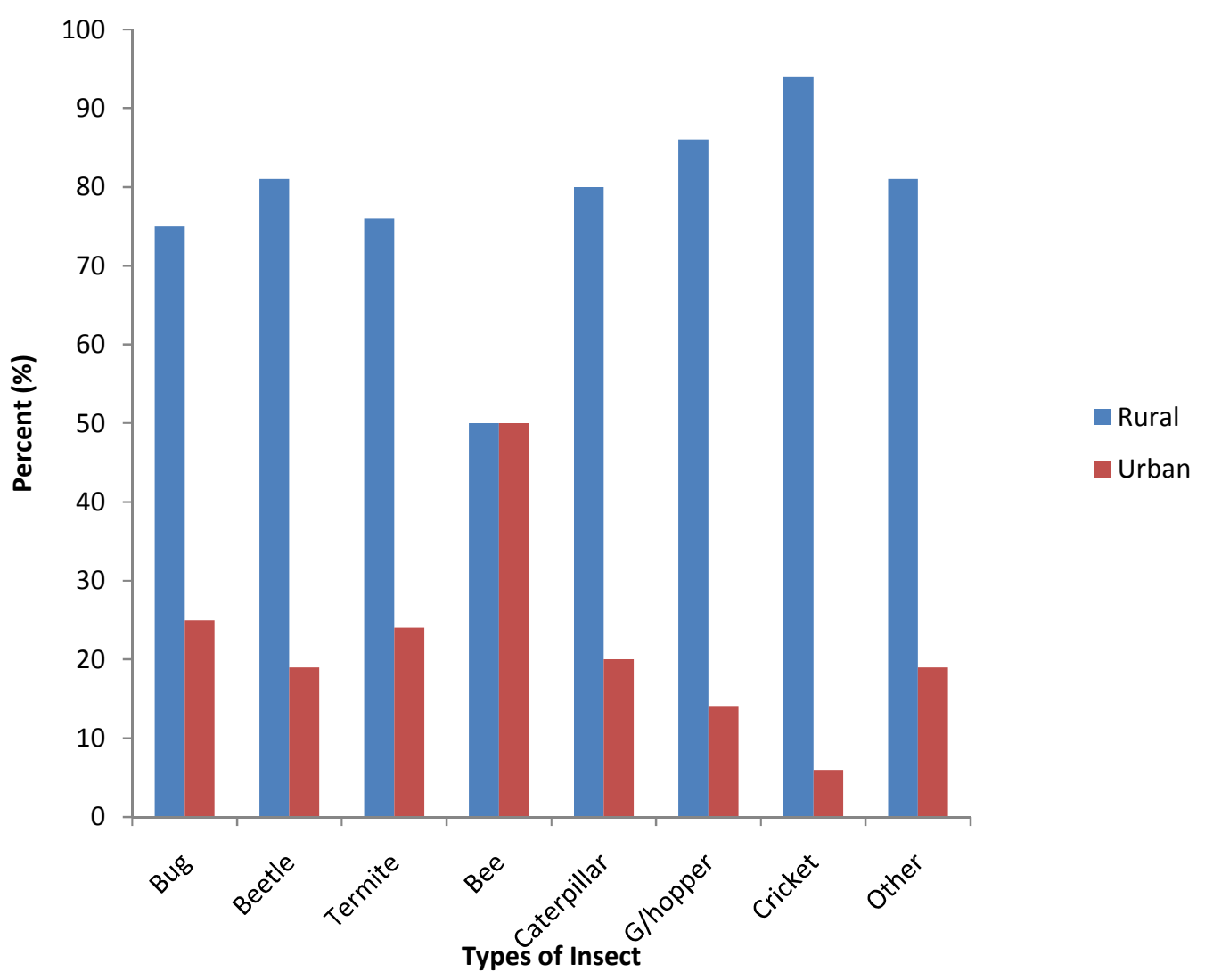

Figure 2: Areas where edible insects are mostly consumed

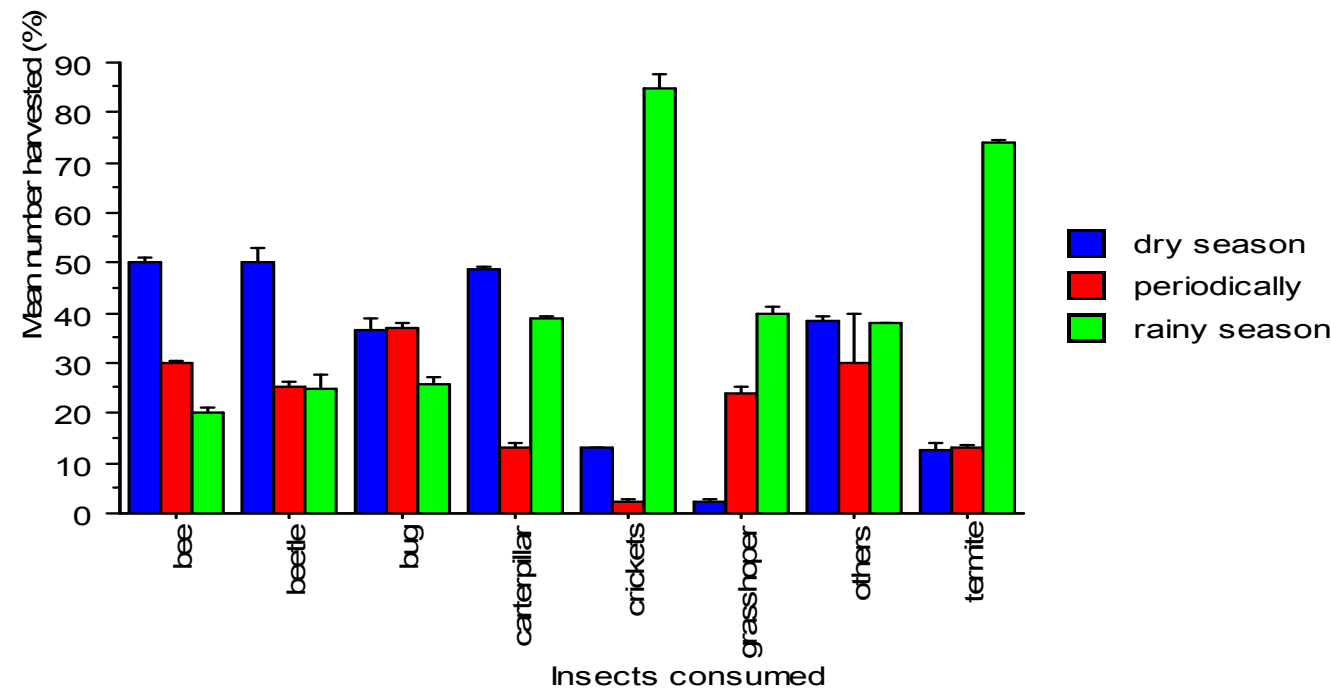

Figure 3: Harvesting period of the edible insects in the sampled local government areas

\subsection{Harvesting methods/frequency}

Significant differences $(p \leq 0.05)$ existed amongst the methods of harvesting the edible insects. Majority of the edible insects identified are always captured from the wild. Five percent of farmers know about trapping of bugs (Lethocerus sp), beetles (O. rhinoceros), bees $(A$. mellifera), termite ( $M$. bellicosus) and caterpillars $(B$. alcinoe) and $10 \%$ of grasshoppers (Z. variegatus), and crickets (B. membranaceus) (Figure 4). On the frequency of harvesting, bugs, beetles, bees and crickets (B. membranaceus) are majorly harvested on monthly basis while termites and caterpillars are harvested once in a year (Figure 5). However, all the insects identified as edible are harvested throughout the year either on daily, weekly, monthly and yearly basis and are majorly harvested by men (Figure 6). 


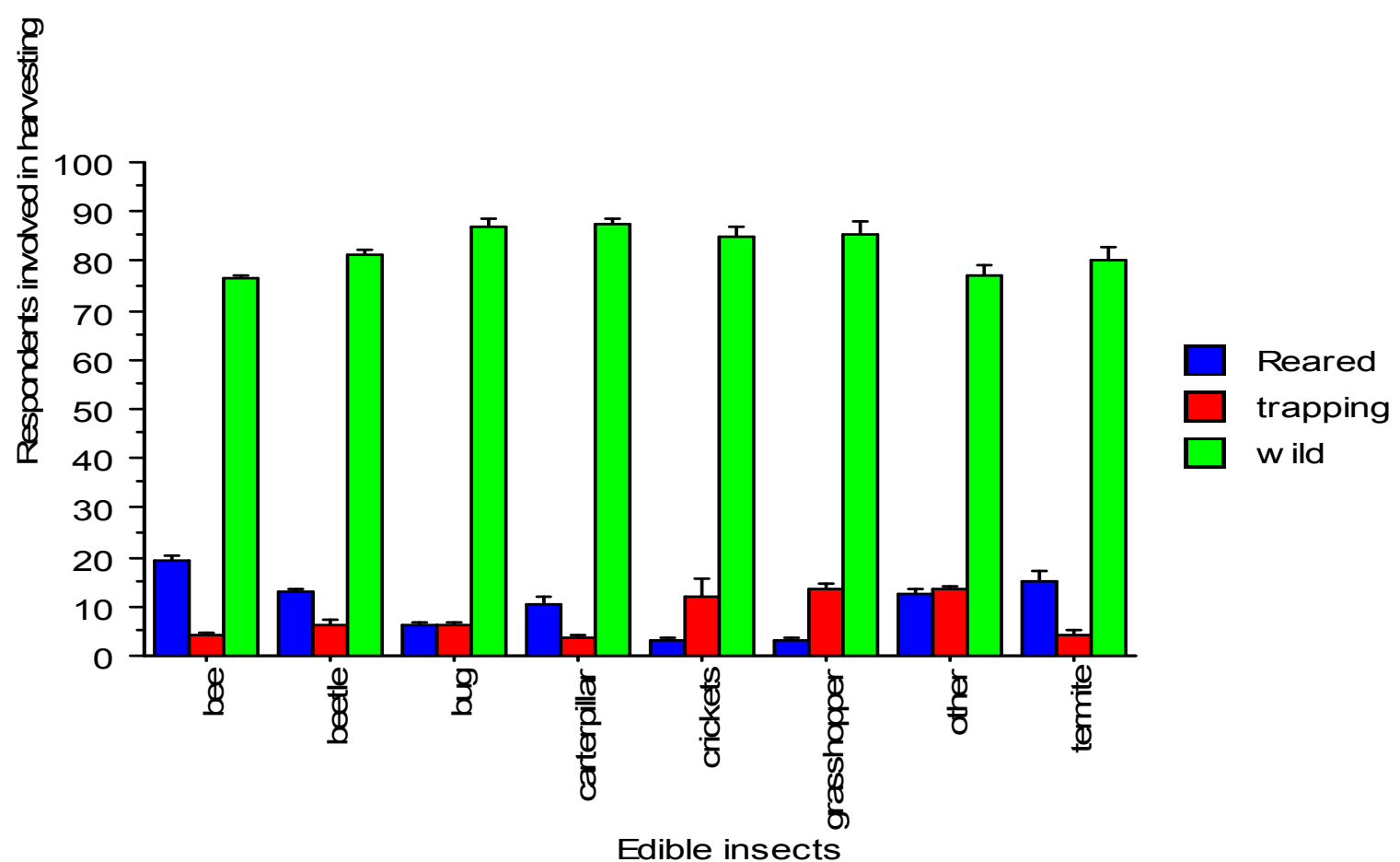

Figure 4: Methods of harvesting edible insects in the sampled areas

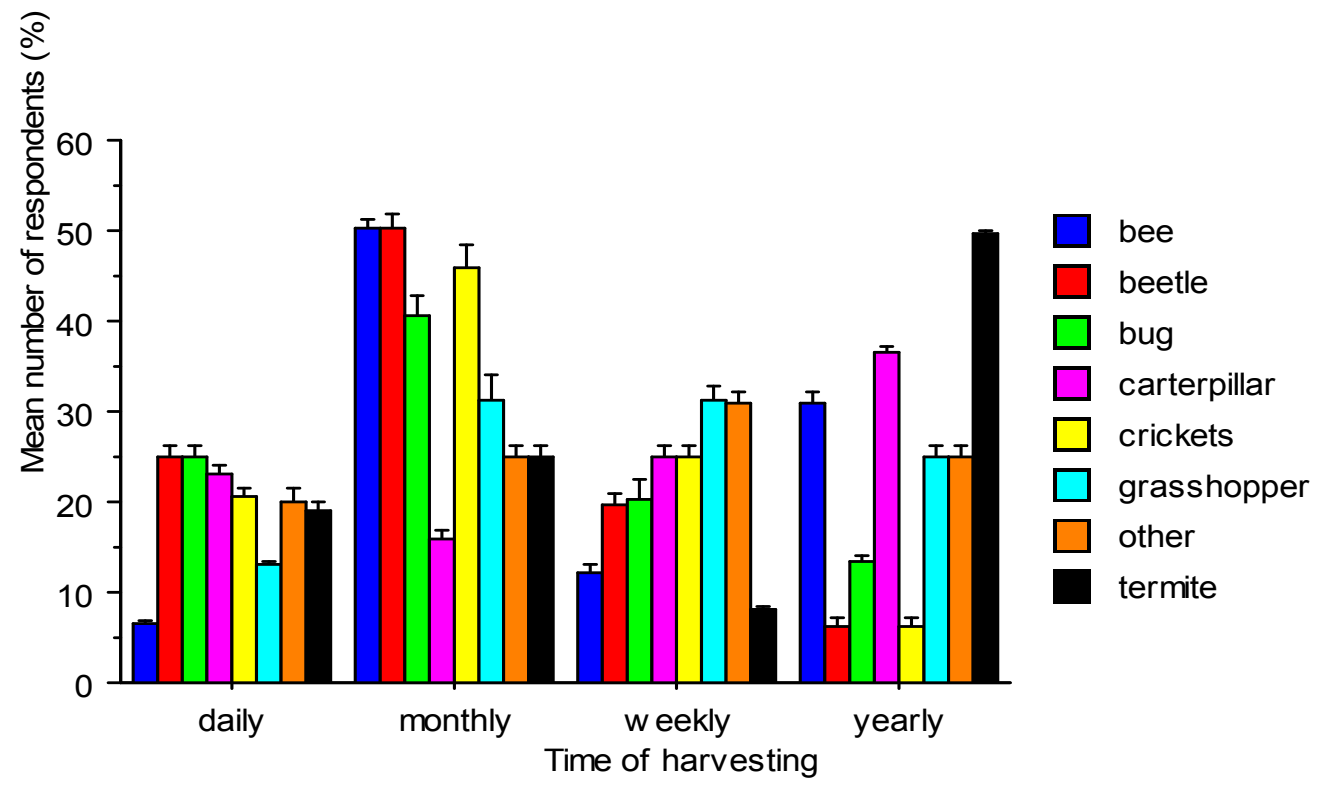

Figure 5: Frequency of harvesting the edible insects in the sampled areas 


\section{Insect Collectors}

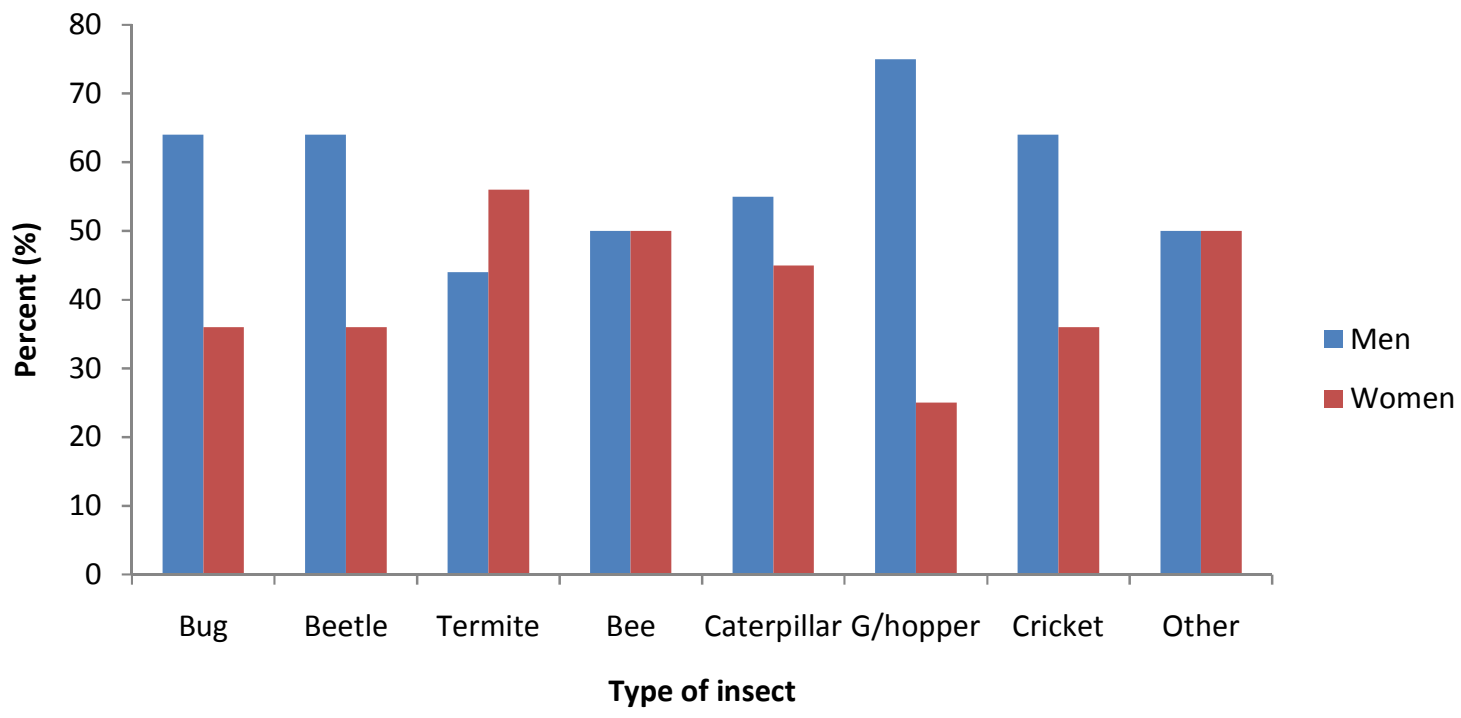

Figure 6: Involvement of respondents on edible insects harvesting

3.6 Methods of processing of edible insects

Results from the study showed that the methods of processing before consumption are frying, roasting, and drying. However, frying and roasting are the significant forms of processing edible insects in the study areas. Bugs (Lethocerus sp), beetles (O. rhinoceros), termites (M. bellicosus), caterpillars (B. alcinoe) and crickets $(B$. membranaceus) are majorly fried before consumption or for storage. Bugs (Lethocerus sp), beetles ( $O$. rhinoceros) are also consumed by roasting while grasshoppers are majorly roasted before consumption. However, bugs (Lethocerus sp), termite ( $M$. bellicosus) and caterpillars $(B$. alcinoe) can be dried in the sun or eaten fresh (Figure 7).

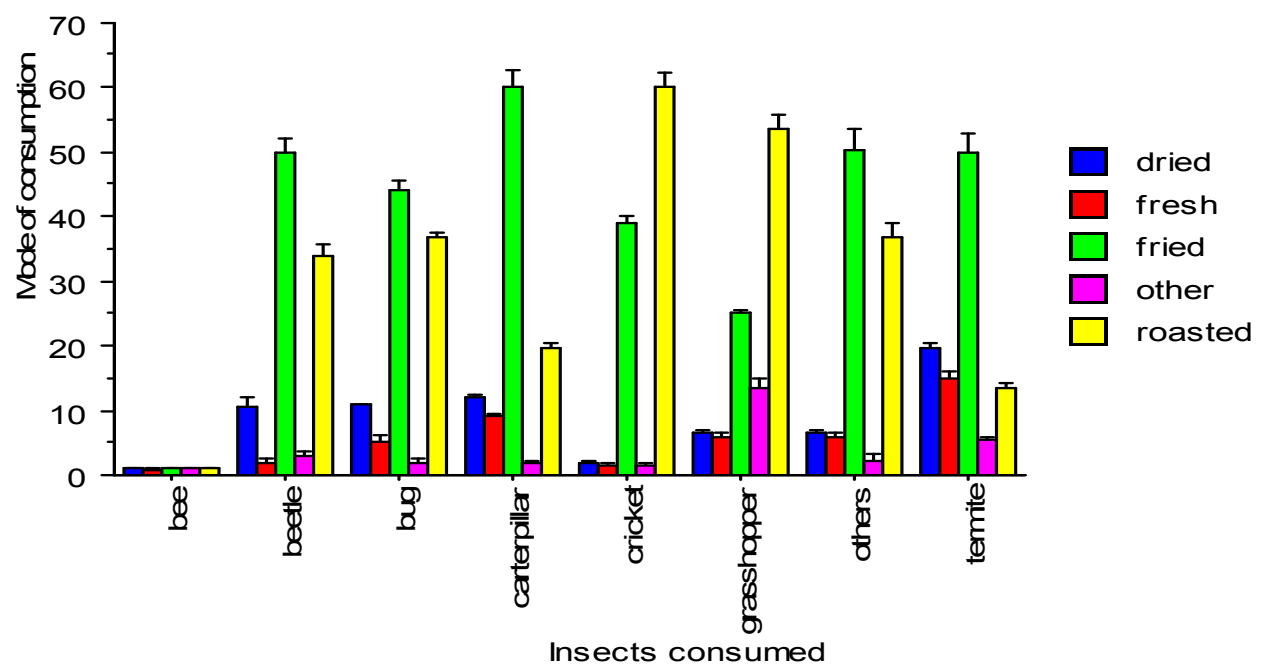

Figure 7: Methods of processing of edible insects in the sampled local government area 


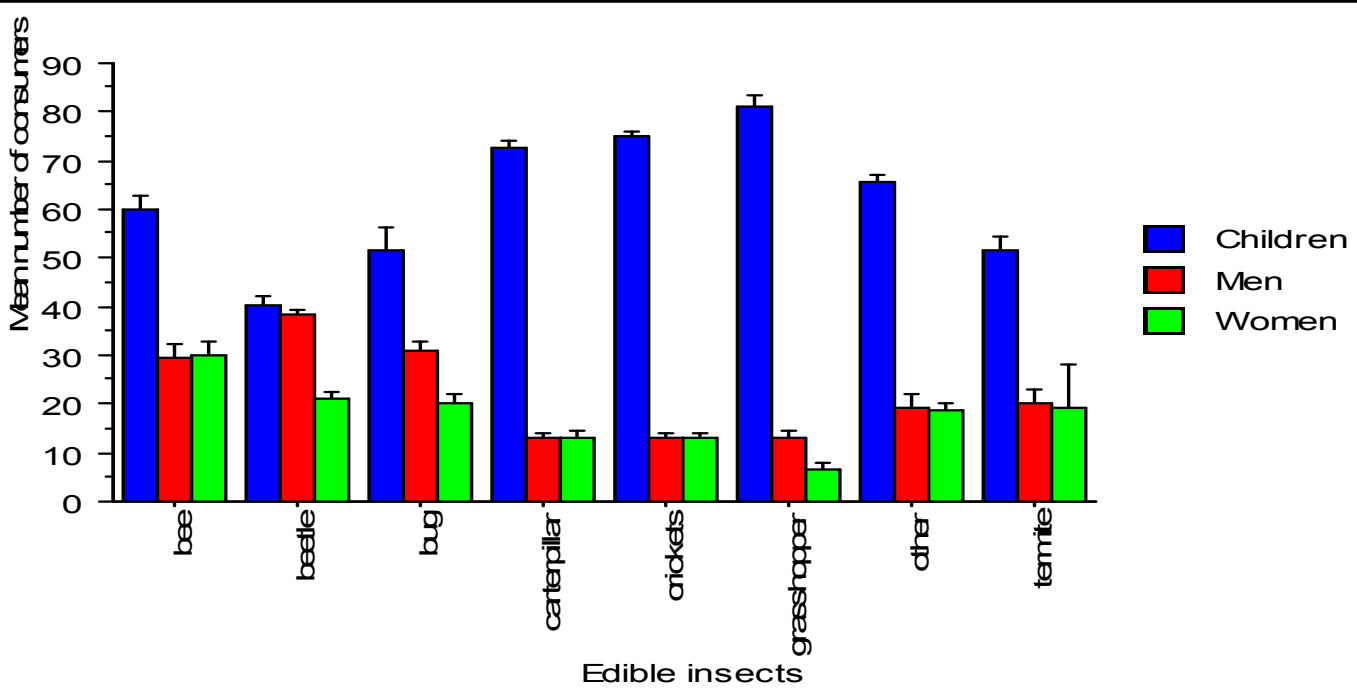

Figure 8: Major consumers of the edible insects in the sampled arears

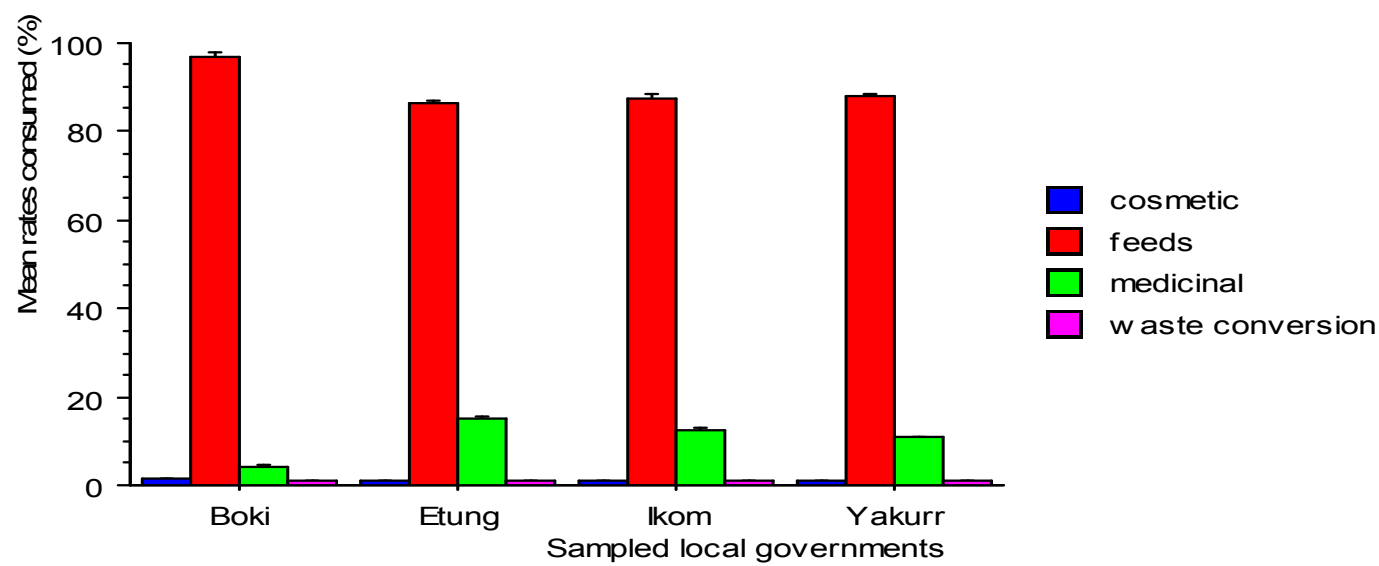

Figure 9: Some importance of the edible insects to the people of Central Senatorial District

\subsection{Socio-economic importance of some selected edible insects}

The result showed a highly significant difference $(p \leq$ 0.05 ) on the level of consumption between young people and adults with children being the most consumers of the edible insect, consuming averagely $80 \%$ while adults consume about $20 \%$ of the edible insects $(13 \%$ by men and $7 \%$ consumed by women) (Figure 8 ).

\subsection{The Socio-economic analysis of the respondents} Results from the four local governments showed that edible insects serve complimentary role in the diets of consumers. They do not constitute the integral part of human diets as not all the farmers are involved in harvesting, processing and consumption of the insects. Less than $30 \%$ of the respondents believed that edible insects serve important role in the diets of humans. About $90 \%$ of the edible insects are used as feeds for both man and livestock while an insignificant value is used for medicinal purposes (Figure 9).

\section{DISCUSSION}

Entomophagy is welcomed among the people of Cross River State especially central zone of the state; it is not new and it cuts across all ages. This is evidenced by the responses obtained from the local community where a total of seven different species belonging to 5 orders namely; Coleoptera, (1 insect species) Isoptera (1 insect species) Orthoptera (2 insect species) Hymenoptera (1 insect species) and Lepidoptera (1 insect species) were documented. The findings of this study agree with the result obtained by Adeduntan and Bata (2004), and Ajayi and Adedire (2007) and Kelemu et al. (2015) who reported that Nigeria is known for the consumption of edible insects such as Macrotermes bellicosus, Bunaea alcinoë, Anaphe panda, Cirina forda, Cirina butyrospermi, Anaphe venata, Orthoptera such as Brachytrupes membranaceus, Nomadacris septemfasciata, Zonocerus variegatus, and coleopteran such as Rhynchophorus phoenicis. In several parts of Western Nigeria, Edo, Delta and Osun states, grubs of palm weevil are fried and eaten. (Banjo et al., 2006). The larvae of the Saturnid Caterpillar (Cirinaforda) known locally as kanniis widely eaten among the people of Kwara state (Adamolekun, 1993).

DeFoliart (2002) reported that about ten (10) different species of edible insects used as food were identified in Cross River which is in conformity with current study. The reported number consumed indicate that insects are cherished by the people of CRC as in many other parts of Nigeria and Africa (Adegbola et al., 2013). The seasonality of the insects as obtained from the study 
agrees with the findings of Van Huis (2015) and Tobih (2013) reported that most insect species occur seasonally depending on the availability of their host plant, however, some may occur throughout the year such as most aquatic insects. Majority of the insects are harvested all year round from the wild. Termites are harvested during the annual nuptial flight (as reported by Banjo et al. (2006) in South Western Nigeria. This agrees with the findings of Garine (1990) cited in FAOMUR (2013) which stated that caterpillars provide an important source of protein during the rainy season (July to October) in the Central African Republic. Smith and Paucar, (2000) opined that vibrations caused by rain and the sound of thunder trigger their emergence. The finding is not in agreement with Yhoung-Aree and Viwatpanich (2005) report on season of harvest for some of the insect species in Lao People's Democratic Republic, Myanmar, Thailand and Vietnam. Chakravorty et al. (2013) also reported on seasonal availability of edible insects According to them, maximum number of edible Coleopterans occurred during June to September (pre monsoon and monsoon) and then got reduced during winter and early spring. The materials from which the insects are harvested showed clearly and support Lale (2010) report that insects co-exist with us and form a part of the food chain. In Tropical countries most insect species are collected from nature. The reason that insects are predominantly eaten in tropical countries is that they are larger and often occur clumped, which facilitates harvesting (Jongema, 2015).

Urban and rural dwellers alike in the study area consume insects, this suggest that insect consumption is widely spread in the area complimenting the protein need of the people. Because many insects are only seasonally available, they are frequently conserved for later consumption. They can be cooked in various ways and served as side dishes eaten with staple food. Cooked edible insects are sold commercially at roadside food stalls as well as markets in various cities of Nigeria (Agbidye et al., 2009). Roasting, boiling and frying in oil were the various methods recorded for preparing the insects for consumption however some were recorded as taken raw (e.g. larva of beetles, $R$. phoenici, winged reproductives of Macrotermes $\mathrm{sp}$ ).

Edible insects constitute the cheapest form of protein source which has the potentials to improve livelihoods and the quality of traditional diets among vulnerable people. The consumption of edible insects has been proposed to remedy the deficiencies of malnutrition caused as a result of deficiencies in both micro and macro minerals in developing countries (Christensen et al., 2005; Gibson, 2015). The result indicated that rural dwellers are the major consumers of the edible insects and there are no good market or hotels for the insects. This may be as a result of lack of information about the consumption of edible insects in tropical countries such as Nigeria and even the little available information are not well documented (Van Huis et al.,2015) irrespective of its benefits to man and animals.

\section{CONCLUSION}

From the present study, it can be concluded that insects consumed (bug, beetle, termite, bee, caterpillars, grasshoppers and cricket) cut across the following orders: Coleoptera, Orthoptera, Isoptera, Lepidotera,
Hemiptera and Diptera. The insects are majorly sourced from the wild at different times of the year and prepared for consumption either by boiling, frying, roasting or sun drying while some are consumed raw. Furthermore, because most edible insect species occur seasonally, and because harvest can be more than what can be consumed in a short time, more research is needed on storage and preservation of these edible insects. Rural dwellers majorly children are the major consumers of edible insects. These insects form an integral part of the diet of the people of the central part of the Cross River State which is consumed by all irrespective of ages. From the foregoing, it is pertinent for research to gear towards rearing and domesticating the insect species which is gradually becoming an integral part of human diet. Therefore, insect consumption by the people of CRC Central Senatorial District should not be taken as an act of poverty but as a matter of choice as many of the insect consumers attested to.

ACKNOWLEDGEMENTS: We wish to acknowledge and appreciate our esteemed respondents for providing information that aided the actualisation of the work.

\section{REFERENCES}

Adamolekun, B., 1993. Anaphe venata entomophagy and seasonal ataxic syndrome in southwest Nigeria. The Lancet, 341, 629. http://dx.doi.org/10.1016/0140-6736(93)90388-

Adeduntan, S. A., Bala, A., 2004. Socio economi importance of local silkworm (Anaphe veneta) to the rural dwellers in Ondo State, Nigeria. Abstract of papers presented at the $35^{\text {th }}$ Annual Conference of the Entomological society of Nigeria held at the Federal University of Akure 3-7 October, 2004. Pp.7.

Adegbola, A.J.;Awagu, F.E.; Arowora, K.; Ojuekaiye, O.; Anugwom, U and Kashetu, Q. R., 2013. Entomophagy: a panacea for protein-deficientmalnutrition and food insecurity in Nigeria. Journal of Agricultural Science 5: 25-31.

Adeoye, O. T.; Oyelowo, O. J.;Adebisi- Fagbohungbe, T. $A$ and Akinyemi, O. D., 2014. EcoDiversity of Edible Insects of Nigeria and Its Impact on Food Security. Journal of Biology and Life Science 5 (2) 175 - 187.

Akpabio, I. A.; Eniang, E. A and Egwali, E. C., 2006. Socio-economic potentials and environmental implications of coastal tourism at Adiabo, Cross River State, Nigeria," Environment, Development and Sustainability, 10: (3) 249265.

Ashiru, M. O., 1988. The food value of the larvae of Anaphe venata Butter (Lepidoptera: Notodontidae). Ecology, Food and Nutrition $22: 313-320$. 
Agbidye, F. S.; Ofuya, T. I and Akindele, S. O., 2009 Some edible Insects species consumed by the people of Benue State, Nigeria. Pakistan Journal of Nutrition, 8(7), 946-950. http://dx.doi.org/10.3923/pjn.2009.946.950

Ajayi, O. E and Adedire, C. O., 2007. Nutrient Characteristics of the Subterranean Termite, Macrotermes subhyalinus (Rambur) (Isopteran: Termitidae). Nigeria Journal of Entomology 24: 42-47.

Akpan - Idoik 2010. Feasibility study of EjeaguYala River Basin Authoirty project Cross River State Ministry of Agriculture.

Banjo, A. D.; Lawal, O. A and Songonuga, E. A., 2006. The nutritional value of fourteen species of edible insects in South-western Nigeria. African Journal of Biotechnology, 5(3), 298 -301.

Boulidam, S., 2010. Edible insects in Lao market economy. InP. B. Durst, D.V. Johnson, R.L. and Shono, L. K. Forest insects as food: Humans bite back, proceedings of a workshop on Asia-Pacific resources and their potential for development, pp. 131-140.

Bangkok, Thailand, FAO Regional Office for Asia and the Pacific.

Bulktrade and Investment Company Limited 1989. Main report on soil and land use survey of Cross River State, Ministry of Agriculture and Natural Resources, Calabar, $376 \mathrm{pp}$

Chakravorty, J.; Ghosh, S and Meyer-Rochow 2013. Comparative Survey of Entomophagy and Entomotherapeutic Practises in Six tribes of Eastern ArunchalPradesh India. Journal of Ethnobiology and Ethnomedicine 9: 50 DOI: 10.1186/1746-4269-9-5.

Christensen, D. L.;Orech, F. O.; Mungai, M. N.; Larsen, T.; Friis, $\mathrm{H}$ and Aagaard-Hansen, J., 2006. Entomophagy among the Luos of Kenya: a potential mineral source. International Journal of Food Science and Nutrition: 57(3/4):198-203.

Defoliart G. R., 2002. The human use of insects as a food Resource: A bibliography account in progress http//www.food-insects.com/book.

Ebenebe, C. I.;M. I.; Udegbala, C.; Ufele, A. N and NwezeB. O., 2017. Survey of edible insect consumption in south-eastern Nigeria. Journal of Insects as Food and Feed: 3 (4): 241-252

FAO/ WUR. 2013. Food and Agriculture Organization and Wagening University Research

Centre. Edible Insect: Future Prospect for Food and Feed Security. FAO Forestry Paper 171. Edited by Arnold Van Huis, Joost Van Litterbeck, Hammett Klunder, Ester martens, Afton Hallowan, Giula Muir and Paul Vantomme 2013.

Garine, I., 1990. Organization of meals, food preferences and socio-economic aspects. In Hladik, C.M., Bahuchet, S. and Garine, I. de (eds), Food and Nutrition in the African Rain Forest, 78-82pp. Paris: UNESCO/CNRS.

Gibson, R. S., 2015. Dietary-induced zinc deficiency in low income countries: challenges and solutions the a Vanelle kirksey lecture at Purdue University. Nutrition Today; 50(1):49-55.

Gordon, D. G., 1998. The Eat-a-Bug Cookbook. Berkely, California: Ten Speed Press.

Jongema, Y., 2015. List of edible insect species of the world. Wageningen: Laboratory of Entomology, Wageningen University, The Netherlands;. http://www.entwurnl/UK/Edible+insects/Worldwi de+species+list/.

Kelemu, S.; Niassy, S.; Torto, B.; Fiaboe, K.; Affognon, H.; Tonnang, H.; Maniania, N.K and Ekesi, S., 2015. African edible insects for food and feed: inventory, diversity, commonalities and contribution to food security. Journal of Insects as Food and Feed, 1(2): 103-119.

Lale, N. E. S., 2010. Stealthy thieves in homes and food stores: Inaugural lecture series No. 68, University of Port-Harcourt, University of PortHarcourt Press Ltd.

Muafor, F. J.; Levang, P.; Ngwafo, T. E and Gall, P. L. E 2012. Making a living with forest insects: beetles as an income source in Southwest Cameroon. International Forestry Review 14(4):1-12

National Population Commission (NPC) 2006. Nigerian national population census report of 2006.

Okore, O.; Avaoja, D and Nwana, F. I., 2014. Edible Insects of the Niger Delta Area in Nigeria. Journal of Natural Sciences Research 4 (5): 1 9

Özalp, P and Emre I., 1998. Effects of Carbohydrates on Levels of Total Glycogen and Protein in Adult Female Pimplaturionellae. Tr. J. of Biology 22:15-19 @ TÜBITAK

Smith, A. B. J and Paucar, C. A., 2000. Taxonomic review of Platycoelalutenscens (Scarabaeidae: Ruleline: Anoplognethium) and a description of its uses as food by the people of Ecuadorian Highlands. Annals of the Entomological Society of America93 (3): 408 414

Srivastava, S. K.; Babu, N and Hema, P., 2009. Traditional insect bioprospecting -As human food and medicine. Indian Journal of Traditional knowledge 8(4), 485-494. 
Tobih, F. O., 2013. Occurrence and Seasonal Variation of Heteroligus meles Billb

(Coleoptera:

Dynastidae) in Upper Niger Delta, Nigeria Agricultural

DOI:10.3923/aj.2011.106.109

UNICEF Nigeria 2015. United Nations International Children's Emergency Fund Maternal and child

healthhttps://www.unicef.org/nigeria/children_19 26.html

Van Huis, A., 2013. Potentials of insects as food and feed in assuring food security. Annual Review of Entomology 58(1): 56-583.

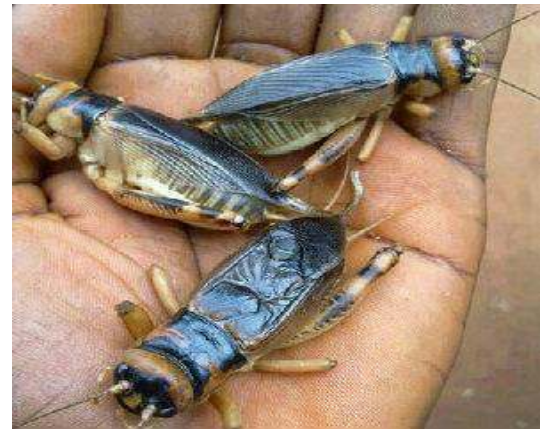

Brachytrupes membranaceus (Drury)

Freshly harvested in Ikom, CRC (Field survey 2018)

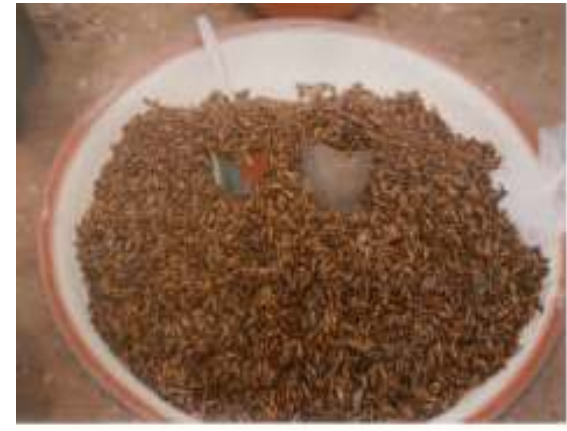

Fried Macrotermesbellicosus for sale (Field survey, 2018)

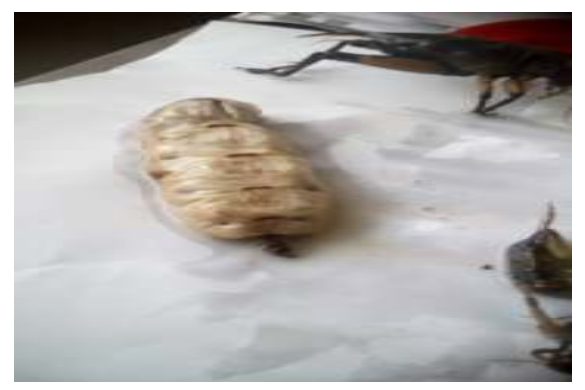

Van Lenteren, J. C., 2006. Ecosystem services to biological control of pests: Proceedings Netherlands Entomological Society Meeting, 17: 103-111.

Van Huis, A.; Van Itterbeeck, J.; Klunder, H.; Mertens, E.; Halloran, A and Muir G., 2015. Edible insects: future prospects for food and feed security. FAO Forestry Paper 171 . Rome Food and Agriculture Organization of the United Nations;

Yhoung-Aree, J and Viwatpanich, K., 2005. Edible insects in the Laos PDR, Myanmar, Thailand, and Vietnam. In M.G. Paoletti, ed. Ecological implications of minilive stock, 415- 440pp. New Hampshire, Science Publishers

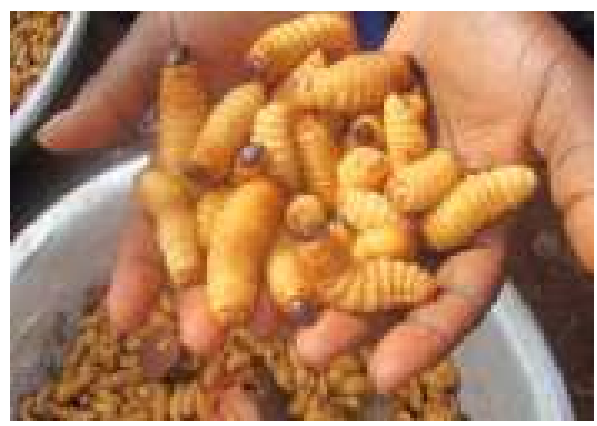

Photo: Larvae (grubs) of the African palm weevil

(Field survey, 2018)

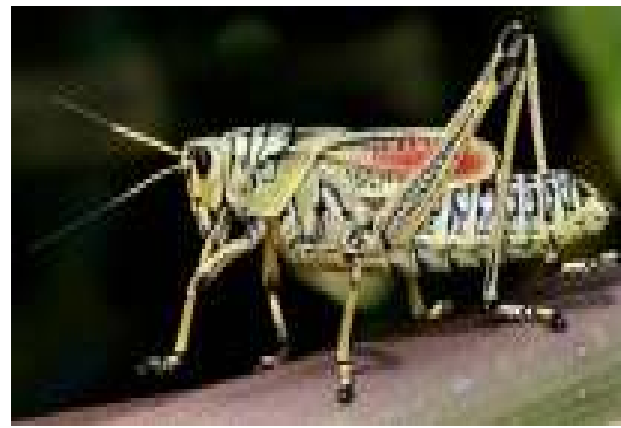

Photo: Grasshopper (Zonocerusvariegatus) (Field survey, 2018)

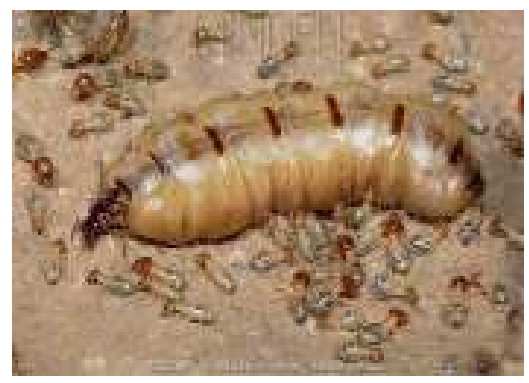

Queen termites obtained from termitarium (Field survey, 2018)

Plate 1: Some common edible insects consumed in Cross River Central. 